\title{
Hydrochemistry and Entropy-Based Groundwater Quality Assessment in the Suining Area, Southwestern China
}

\author{
Yunhui Zhang $\mathbb{D},{ }^{1,2}$ Xiao Li $\mathbb{D},{ }^{3}$ Ming Luo, ${ }^{4}$ Changli Wei, ${ }^{4}$ Xun Huang, ${ }^{1}$ Yong Xiao $\mathbb{D}^{1,2}$ \\ Limao Qin, ${ }^{1}$ and Qiuming Pei $\mathbb{C}^{1}$ \\ ${ }^{1}$ Faculty of Geosciences and Environmental Engineering, Southwest Jiaotong University, Chengdu 611756, China \\ ${ }^{2}$ Yibin Research Institute, Southwest Jiaotong University, Yibin 644000, China \\ ${ }^{3}$ State Key Laboratory of Geohazard Prevention and Geoenvironment Protection, College of Environment and Civil Engineering, \\ Chengdu University of Technology, Chengdu 610059, China \\ ${ }^{4}$ Sichuan Institute of Geological Survey, Chengdu 610081, China \\ Correspondence should be addressed to Xiao Li; lixiao@cdut.edu.cn
}

Received 10 February 2021; Accepted 27 May 2021; Published 8 June 2021

Academic Editor: Xubo Gao

Copyright (c) 2021 Yunhui Zhang et al. This is an open access article distributed under the Creative Commons Attribution License, which permits unrestricted use, distribution, and reproduction in any medium, provided the original work is properly cited.

\begin{abstract}
Groundwater is an essential resource for sustainable development, whose quality is significant for human health. In the present study, twenty-eight groundwater samples were collected from domestic tube wells and public water supply wells in the Suining area, southwestern China. The integration of statistical analysis, correlations of ions, geomodelling, and entropy-weighted water quality index (EWQI) was carried out to clarify the hydrochemistry and groundwater quality in the study area. By the statistical analysis, the cations followed the concentration order as $\mathrm{Ca}^{2+}>\mathrm{Na}^{+}>\mathrm{Mg}^{2+}>\mathrm{K}^{+}$, while anions' concentrations were $\mathrm{HCO}_{3}{ }^{-}>\mathrm{SO}_{4}{ }^{2-}>\mathrm{Cl}^{-}>\mathrm{NO}_{3}{ }^{-}>\mathrm{F}^{-}$. Piper trilinear diagram showed the hydrochemical type was characterized as $\mathrm{Ca}-\mathrm{HCO}_{3}$. Correlations of ions and geomodelling revealed the concentrations of major ions were mainly determined by carbonate dissolution and ion exchange process, and $\mathrm{NO}_{3}{ }^{-}$concentrations were controlled by agriculture activities. EWQI computation demonstrated that most of the groundwater samples possessed EWQI values higher than 100. Therefore, groundwater quality is lower than the permissible limit of the World Health Organization (WHO), suitable for drinking purposes in the Suining area. Our study provides vital knowledge for groundwater management in the Suining and other similar areas.
\end{abstract}

\section{Introduction}

Groundwater is the basic and vital resource for humans living around the world. However, groundwater quality is deteriorating due to the rapid development of industrialization and urbanization, great growth of population, and excessive use of fertilizers [1-3]. So far, groundwater has been contaminated by nitrate, fluoride, arsenic, heavy metal elements, etc., seriously threatening to human health [4-8]. Comprehensive investigations of groundwater chemistry, mechanism analysis, and quality evolution can provide robust information for groundwater protection, which have been carried out globally [9-11].

Understanding groundwater chemistry is the critical fundament for mechanism analysis and quality evolution
[12-14]. For numerous hydrochemical data, a statistical approach is used to analyse the general scope, which is shown in the Box-Whisker diagram [15]. The Piper trilinear diagram can present the water type clearly [16]. The mechanism for groundwater chemistry is mainly determined by natural processes and anthropogenic activities [17-19]. Natural processes generally consist of water-rock interaction, precipitation, and evaporation. Gibbs plots are regarded as the classic approach to distinguish the natural governing factors affecting groundwater chemistry [20]. Correlations of different ions and geomodelling can further constrain the rock type involving water [21]. Assessment of groundwater quality is a hot topic for numerous researchers. In the previous study, the traditional water quality index (WQI) was introduced to evaluate groundwater quality 
firstly [22-24]. Considering the various hydrochemical parameters, the WQI approach is not efficient to reveal the groundwater quality. The methodology for evaluating groundwater quality has experienced several stages from the traditional water quality index (WQI) to entropy water quality index (EWQI). The EWQI with entropy values involving various hydrochemical parameters has been believed to be a more robust approach due to its more comprehensive computation [19, 25-29]. In addition, the Geography Information System software (GIS) is helpful to reveal the spatial distribution of EWQI values. Therefore, the EWQI analysis has been extensively conducted for groundwater quality evaluation.

The Chengdu Plain is the area where industrialization and urbanization are rapidly increasing since the national developing strategy of the Chengdu-Chongqing economic circle was generated in the year 2020. The Suining area is an important city in the Chengdu Plain with a population of 3.6 million. The agriculture industry is active in the Suining area where the lands of 389 thousand hectares are exploited for extensive agricultural activity. However, scarce research has so far been conducted to understand the comprehensive evaluation of groundwater chemistry and quality from the Suining area. Therefore, the objectives of our study are as follows: (1) investigating the preliminary characteristics of groundwater chemistry, (2) identifying the factors controlling groundwater chemistry, and (3) evaluating groundwater quality using EWQI. The achievements of our study are hopeful to provide references for effective groundwater protection and management in future.

\section{Materials and Methods}

2.1. Study Area. The Suining area is located in the eastern part of the Sichuan Province, southwestern China, within

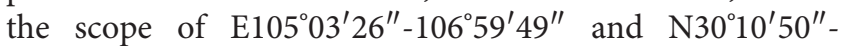
$31^{\circ} 10^{\prime} 50^{\prime \prime}$ (Figure 1). The study area belongs to a subtropical humid monsoon climate with an annual temperature of $17^{\circ} \mathrm{C}$ and annual precipitation of $900 \mathrm{~mm}$. The geomorphology is characterized as hilly and low mountain areas, with an elevation of $300-600 \mathrm{~m}$. Rivers are developed in the Suining area where the Fu River is the dominant river (Figure 1).

The study area is situated in the Central Sichuan fold belt [30]. The strata are composed of the Quaternary sediments, Jurassic-Cretaceous calcareous mudstones and sandstones, and Triassic limestones (Figure 2) [31]. The Quaternary sediments contain sands, gravels, silty clay, and clay. The Jurassic-Cretaceous calcareous mudstones and sandstones consist of clay minerals (hydromica, kaolinite, and montmorillonite), detrital minerals (quartz, feldspar, and mica), and calcite. The Triassic limestones are dominated by calcite with less dolomite. Structures are not developed in the Suining area except for some E-W-trending wide folds. Groundwater mainly includes pore fissure water and fissure water and is recharged by infiltration of precipitation and local runoff. The Jurassic-Cretaceous calcareous sandstones are the main aquifers, while the mudstones are identified as confining beds [12]. The depth of groundwater is shallow and lower than $20 \mathrm{~m}$. So far, groundwater has been exploited by local residents for domestic and irrigation goals.

2.2. Field Sampling and Laboratory Measurements. In this study, a total of twenty-eight groundwater samples were collected within the Suining area from groundwater wells during June 2016. Sampling sites were equally distributed in the study area. Prior to sampling, at least ten minutes were taken to pump stagnant water in the wells. Every sample bottle was rinsed three times by the sample water. All of the groundwater samples were analysed for hydrochemical compositions in the Laboratory of the Sichuan Provincial Bureau of Geology and Mineral Resources. Total dissolved solids (TDS) and major cations (e.g., $\mathrm{K}^{+}, \mathrm{Na}^{+}, \mathrm{Ca}^{2+}$, and $\mathrm{Mg}^{2+}$ ) were analysed by an atomic absorption spectrophotometer (AA6100; Techcomp, China). $\mathrm{Cl}^{-}, \mathrm{SO}_{4}{ }^{2-}, \mathrm{NO}_{3}{ }^{-}$, and $\mathrm{F}^{-}$were measured using ion chromatography (IC6100; Wayee, China). Chemical oxygen demand (COD) and total hardness $(\mathrm{TH})$ and $\mathrm{HCO}_{3}{ }^{-}$were determined by titration. The charge balance error (CBE) ranged from $-4.14 \%$ to $+0.43 \%$ (calculated based on Equation (1)), validating the accuracy of experimental analyses:

$$
\mathrm{CBE}=\frac{\sum \text { cations }-\sum \text { anions }}{\sum \text { cations }+\sum \text { anions }} \times 100 \% .
$$

2.3. Data Processing and Analysis. The statistical analysis for hydrochemical parameters was compiled based on SPSS 25 . Piper diagram was drawn by AquaChem software version 3.0, showing the hydrochemical type.

The Materials and Methods section should contain sufficient detail so that all procedures can be repeated. It may be divided into headed subsections if several methods are described. The saturation index (SI) of specific minerals was computed using PHREEQC 3.0, based on the following equation:

$$
\mathrm{SI}=\log \left(\frac{\mathrm{IAP}}{K}\right)
$$

where IAP represents ion activity in groundwater and $K$ is the solubility constant under specific temperature.

The entropy-weighted water quality index (EWQI) is the approach for evaluating water quality by entropy value involving various hydrochemical parameters. In general, the EWQI values were computed by four steps as follows:

Step 1: the eigenvalue matrix $X$ is obtained as follows:

$$
X=\left[\begin{array}{cccc}
x_{11} & x_{12} & \cdots & x_{1 n} \\
x_{21} & x_{22} & \cdots & x_{2 n} \\
\vdots & \vdots & \ddots & \vdots \\
x_{m 1} & x_{m 2} & \cdots & x_{m n}
\end{array}\right],
$$

where $m$ is the total number of water samples and $n$ signifies the number of hydrochemical parameters.

Step 2: the standard evaluation matrix " $Y$ " is calculated as follows: 


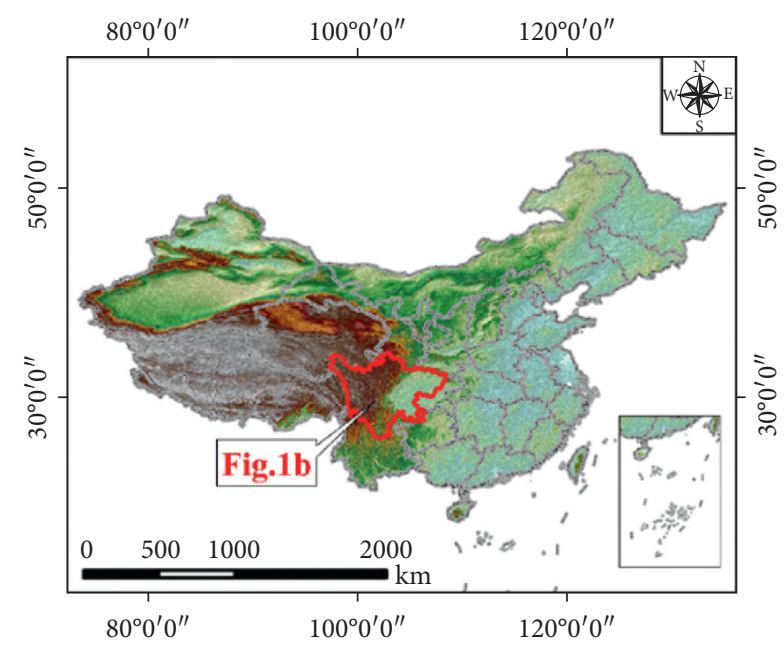

(a)

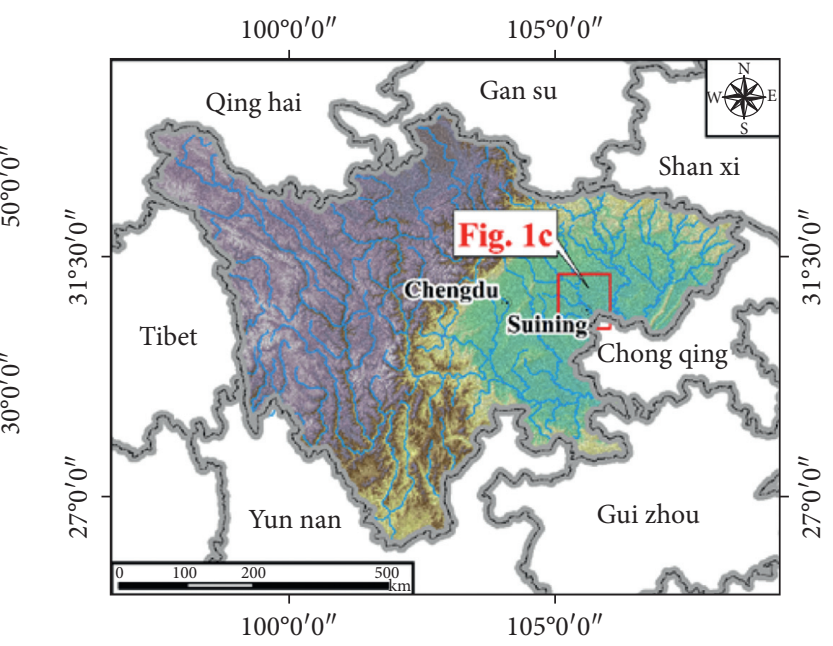

(b)

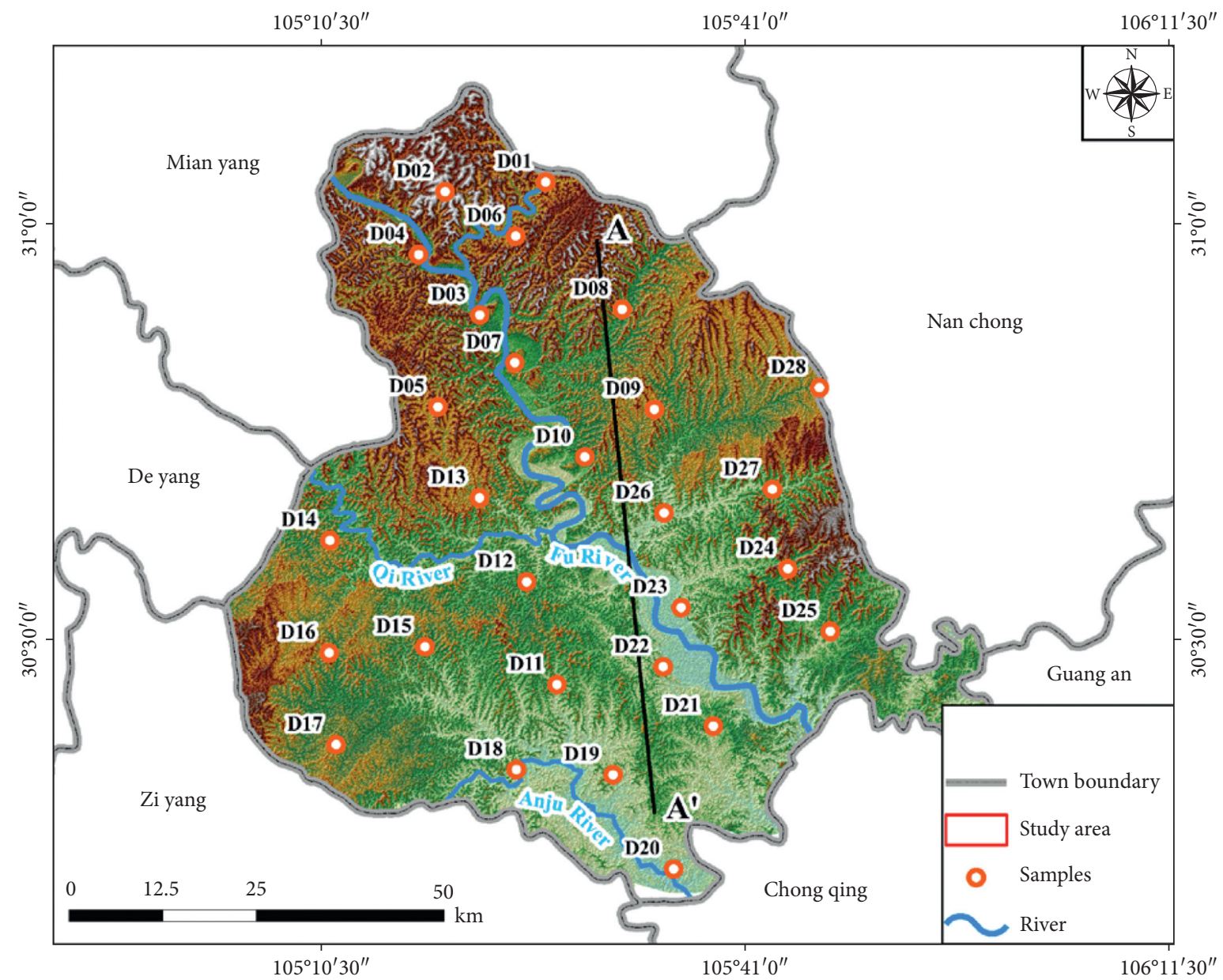

(c)

Figure 1: Study area location and sampling point distribution. 


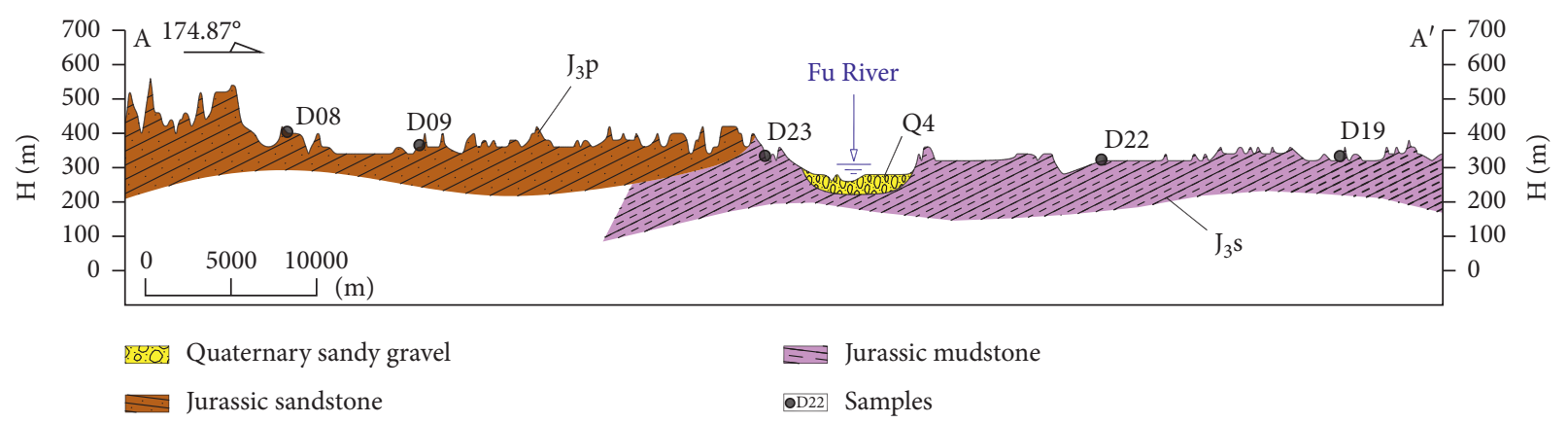

Figure 2: Geological section A-A' of the study area.

$$
\begin{aligned}
& y_{i j}= \begin{cases}\frac{x_{i j}-\left(x_{i j}\right)_{\min }}{\left(x_{i j}\right)_{\max }-\left(x_{i j}\right)_{\min }}, & \text { benefit type, } \\
\frac{\left(x_{i j}\right)_{\max }-x_{i j}}{\left(x_{i j}\right)_{\max }-\left(x_{i j}\right)_{\min }}, & \text { cost type, }\end{cases} \\
& Y=\left[\begin{array}{cccc}
y_{11} & y_{12} & \cdots & y_{1 n} \\
y_{21} & y_{22} & \cdots & y_{2 n} \\
\vdots & \vdots & \ddots & \vdots \\
y_{m 1} & y_{m 2} & \cdots & y_{m n}
\end{array}\right],
\end{aligned}
$$

where $\left(x_{i j}\right)_{\max }$ and $\left(x_{i j}\right)_{\min }$ are the maximum and minimum values of the hydrochemical parameters of the water samples, respectively, and " $y_{i j}$ " is the standardization process.

Step 3: the information entropy " $e_{j}$ " is acquired as follows:

$$
e_{j}=-\frac{1}{\ln m} \sum_{i=1}^{m}\left(P_{i j} \times \ln P_{i j}\right) \text {, }
$$

where $P_{i j}$ is the parameter value ratio of parameter $j$ for sample $i$, achieved based on Equation (6):

$$
P_{i j}=\frac{y_{i j}}{\sum_{i}^{m} y_{i j}} .
$$

Afterwards, the entropy weight " $w_{j}$ " can be obtained as follows:

$$
w_{j}=\frac{1-e_{j}}{\sum_{i=1}^{n}\left(1-e_{j}\right)} .
$$

Step 4: the quality rating scale " $q_{j}$ " of each parameter could be computed by the following equation:

$$
q_{j}=\frac{C_{j}}{S_{j}} \times 100,
$$

where $C_{j}$ is the concentration of each hydrochemical parameter $j$ and $S_{j}$ represents the permissible limit of the World Health Organization standards for specific hydrochemical parameter $j$.
Finally, the EWQI value can be computed using the following equation:

$$
\mathrm{EWQI}=\sum_{j=1}^{m}\left(w_{j} \times q_{j}\right) .
$$

The classification of water quality based on EWQI is shown in Table 1.

\section{Results and Discussion}

3.1. General Characteristics of Groundwater Chemistry. The statistical results of hydrochemical parameters are presented in Table 2 and Figure 3, which were compared with the standard limits of the World Health Organization (WHO). The $\mathrm{pH}$ values varied from 7.1 to $8.4($ mean $=7.6)$, indicating neutral to slightly alkaline character and permissible for drinking purpose. Total dissolved solids (TDS) had concentrations of $20-830 \mathrm{mg} / \mathrm{L}$, within the permissible drinking standard. The total hardness $(\mathrm{TH})$ values ranged from $160.14 \mathrm{mg} / \mathrm{L}$ to $550.50 \mathrm{mg} / \mathrm{L} \quad($ mean $=389.99 \mathrm{mg} / \mathrm{L})$. $17.86 \%$ of groundwater samples exceeding the permissible limit of $450.00 \mathrm{mg} / \mathrm{L}$ displayed the hard to very hard affinity (Figure 4(a)) and were unsuitable for drinking. Based on the statistical results, the major cations and anions followed the order of concentrations as follows: $\mathrm{Ca}^{2+}(46.10-184.40 \mathrm{mg} /$ $\mathrm{L})>\mathrm{Na}^{+}(8.70-78.00 \mathrm{mg} / \mathrm{L})>\mathrm{Mg}^{2+}(6.10-42.60 \mathrm{mg} / \mathrm{L})>\mathrm{K}^{+}$ $(0.90-25.00 \mathrm{mg} / \mathrm{L})$, and $\mathrm{HCO}_{3}{ }^{-}(140.30-530.90 \mathrm{mg} / \mathrm{L})$ $>\mathrm{SO}_{4}{ }^{2-}(45.90-207.00 \mathrm{mg} / \mathrm{L})>\mathrm{Cl}^{-}(7.20-90.50 \mathrm{mg} / \mathrm{L}) . \mathrm{Ca}^{2+}$ and $\mathrm{HCO}_{3}{ }^{-}$were the dominated cation and anion, respectively, characterized as the hydrochemical type of $\mathrm{Ca}-$ $\mathrm{HCO}_{3}$ (Figure 4(b)). Most of the major ions (except $\mathrm{Ca}^{2+}$ ) possessed concentrations less than the permissible limit for drinking purpose (Table 2). Of note, the $\mathrm{NO}_{3}{ }^{-}, \mathrm{NO}_{2}{ }^{-}$, and $\mathrm{NH}_{4}{ }^{+}$concentrations of groundwater samples were found beyond the permissible limit. Among them, $\mathrm{NO}_{3}{ }^{-}$had the highest concentrations of $0.20-244.00 \mathrm{mg} / \mathrm{L}$, with $50 \%$ of groundwater samples exceeding the maximum allowable limit of $50 \mathrm{mg} / \mathrm{L} . \mathrm{NO}_{2}{ }^{-}$and $\mathrm{NH}_{4}{ }^{+}$concentrations varied from 0.01 to $6.05 \mathrm{mg} / \mathrm{L}$ and 0.03 to $1.53 \mathrm{mg} / \mathrm{L}$, within $18.57 \%$ and $11.43 \%$ of groundwater samples exceeding the permissible limit, respectively. Hence, nitrate contamination was identified in the Suining area. The $\mathrm{F}^{-}$concentrations (0.2-0.6 mg/L) were obviously lower than the recommended level of drinking water standard. 
TABLE 1: Classification criteria of water quality based on EWQI, according to reference [25].

\begin{tabular}{lcc}
\hline Rank & EWQI & Water quality \\
\hline 1 & $<50$ & Excellent \\
2 & $50-100$ & Good \\
3 & $100-150$ & Medium \\
4 & $150-200$ & Poor \\
5 & $>200$ & Extremely poor \\
\hline
\end{tabular}

TABLE 2: Statistical results of hydrochemical parameters and drinking water standards.

\begin{tabular}{|c|c|c|c|c|c|c|c|}
\hline Parameters & Max & Min & Mean & SD & CV (\%) & Guideline & $\%$ of SEL \\
\hline $\mathrm{pH}$ & 8.4 & 7.10 & 7.6 & 0.25 & 3.37 & $6.5-8.5^{*}$ & 0.00 \\
\hline TDS & 830 & 201 & 563 & 140 & 24.90 & $1000^{*}$ & 0.00 \\
\hline $\mathrm{TH}$ & 550.50 & 160.14 & 389.99 & 89.04 & 22.83 & $450.00^{*}$ & 17.86 \\
\hline $\mathrm{K}^{+}$ & 25.00 & 0.90 & 3.75 & 4.77 & 126.98 & - & - \\
\hline $\mathrm{Na}^{+}$ & 78.00 & 8.70 & 31.66 & 14.81 & 46.76 & $200^{* *}$ & 0.00 \\
\hline $\mathrm{Ca}^{2+}$ & 184.40 & 46.10 & 118.68 & 30.67 & 25.85 & $75^{* *}$ & 92.86 \\
\hline $\mathrm{Mg}^{2+}$ & 42.60 & 6.10 & 22.75 & 8.68 & 38.14 & $50^{* *}$ & 0.00 \\
\hline $\mathrm{Cl}^{-}$ & 90.50 & 7.20 & 30.62 & 22.98 & 75.06 & $250^{*}$ & 0.00 \\
\hline $\mathrm{SO}_{4}{ }^{2-}$ & 207.00 & 45.90 & 93.60 & 42.20 & 45.09 & $250^{*}$ & 0.00 \\
\hline $\mathrm{HCO}_{3}{ }^{-}$ & 530.90 & 140.30 & 348.31 & 89.41 & 25.67 & - & - \\
\hline $\mathrm{NO}_{3}^{-}$ & 244.00 & 0.20 & 68.12 & 61.42 & 90.17 & $50^{* *}$ & 50.00 \\
\hline $\mathrm{NO}_{2}^{-}$ & 6.05 & 0.01 & 0.43 & 1.41 & 327.39 & $0.02^{*}$ & 18.57 \\
\hline $\mathrm{NH}_{4}{ }^{+}$ & 1.53 & 0.03 & 0.23 & 0.30 & 129.05 & $0.2^{*}$ & 11.43 \\
\hline $\mathrm{F}^{-}$ & 0.6 & 0.2 & 0.4 & 0.10 & 27.16 & $1.0^{*}$ & 0.00 \\
\hline
\end{tabular}

SD, standard deviation; CV (\%), coefficient of variation; ${ }^{*}$ Chinese Guidelines [32]; ${ }^{* *}$ WHO Guidelines [33]; \% of SEL, $\%$ of samples exceeding the acceptable limit.

3.2. Factors Controlling Groundwater Chemistry. The natural sources controlling ion concentrations generally include evaporation, rock weathering, and precipitation. Gibbs raised the classified diagram for distinguishing the different natural sources [34]. In the Gibbs diagram, all groundwater samples are plotted in the area of rock dominance (Figure 5), indicating that water-rock interaction is the natural process determining the ion concentrations of groundwater.

\subsection{Sources of Major Ions}

3.3.1. Correlation of Major Ions for Mineral Dissolution. The correlation of major ions has been extensively used to clarify the mineral types involving the water-rock interaction (Figure 6). When the dissolution of halite is the main process, the mole ratio between $\mathrm{Cl}^{-}$and $\mathrm{Na}^{+}$is equal to one. Most of the groundwater samples plotted below the $y=x$ line, against the possibility of halite dissolution. The excess $\mathrm{Na}^{+}$concentration was probably derived from silicate dissolution or ion exchange. The dissolution of gypsum would lead to the molar ratio between $\mathrm{SO}_{4}{ }^{2-}$ and $\mathrm{Ca}^{2+}$ equal to one. All of the groundwater samples drifted under the $y=x$ line. The dissolution of gypsum was unlikely to be the main natural process, implying there are possibilities that some processes contribute $\mathrm{Ca}^{2+}$. In the $\mathrm{Ca}^{2+}$ vs. $\mathrm{HCO}_{3}{ }^{-}$, groundwater samples followed the $y=x$ line, implying the occurrence of calcite dissolution. Molar concentrations of $\mathrm{Ca}^{2+}, \mathrm{Mg}^{2+}, \mathrm{Na}^{+}$, and $\mathrm{HCO}_{3}{ }^{-}$constructed by Gaillardet et al. (1999) have been considered as the efficient approach to evaluate the effects of carbonate rocks, silicate rocks, and evaporite rocks on the hydrochemical compositions [35]. In this study, groundwater samples fell in the zone between the carbonate rocks and silicate rocks. Hence, silicates and carbonates rather than evaporites had a contribution to groundwater chemistry. Accordantly, groundwater samples were distributed in the areas of silicate weathering and calcite dissolution.

Ion exchange has been reported as the natural process universally occurring in the groundwater system [36-38]. The relationship between $\left(\mathrm{Ca}^{2+}+\mathrm{Mg}^{2+}\right)-\left(\mathrm{SO}_{4}{ }^{2-}+\mathrm{HCO}_{3}{ }^{-}\right)$ and $\left(\mathrm{Na}^{+}+\mathrm{K}^{+}-\mathrm{Cl}^{-}\right)$can be employed to identify the ion exchange. The plots of groundwater samples displayed a negative correlation, revealing the ion exchange existed between $\mathrm{Ca}^{2+}$ and $\mathrm{Na}^{+}$. Moreover, the chloroalkaline indices (CAI-I and CAI-I) are feasible to constrain the type of ion exchange. When the CAI-I and CAI-II values are higher than zero, reverse ion exchange occurs. In contrast, ion exchange is supported by the CAI-I and CAI-II values lower than zero. In this study, most of the groundwater samples possessed the CAI-I and CAI-II values lower than zero. Hence, ion exchange between $\mathrm{Ca}^{2+}$ and $\mathrm{Na}^{+}$was proposed in the study area.

3.3.2. Saturation Index for Estimating Possible Mineral Phases. Saturation index (SI) is viable to reflect the mineral equilibrium state in the groundwater system. In this study, saturation indices of calcite, dolomite, gypsum, and halite were computed by Phreeqc 3.0, as shown in Figure 6(i). The 

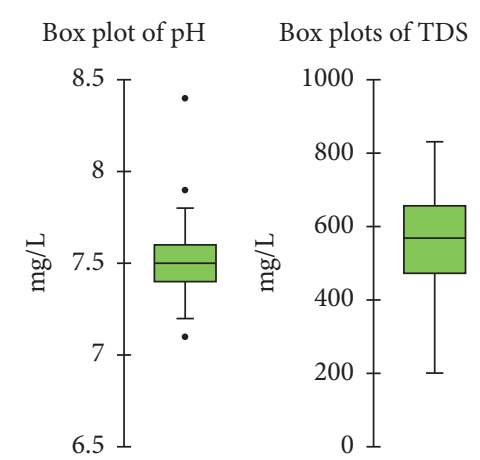

Box plots of $\mathrm{Ca}^{2+}$

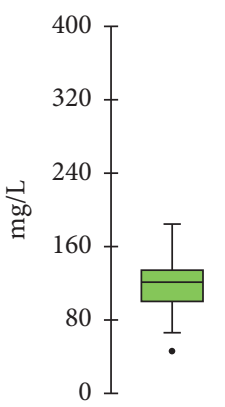

Box plots of $\mathrm{NO}_{3}^{-}$

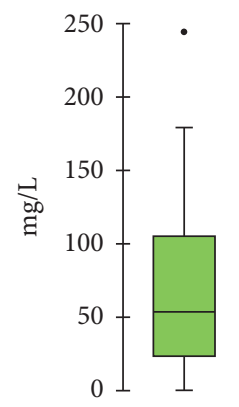

Box plots of $\mathrm{Mg}^{2+}$

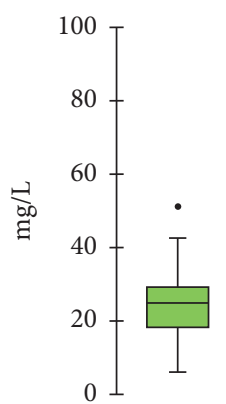

Box plots of $\mathrm{NO}_{2}^{-}$

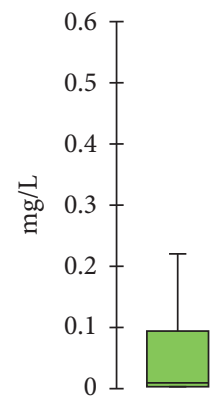

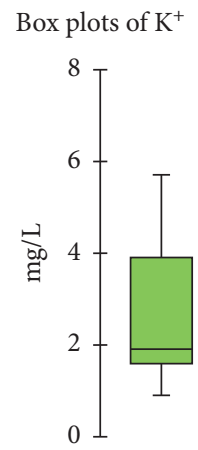

Box plots of $\mathrm{Na}^{+}$

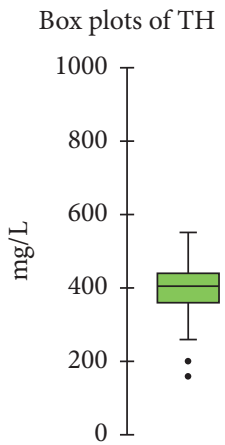

Box plots of $\mathrm{Cl}^{-}$

Box plots of $\mathrm{SO}_{4}^{2-}$
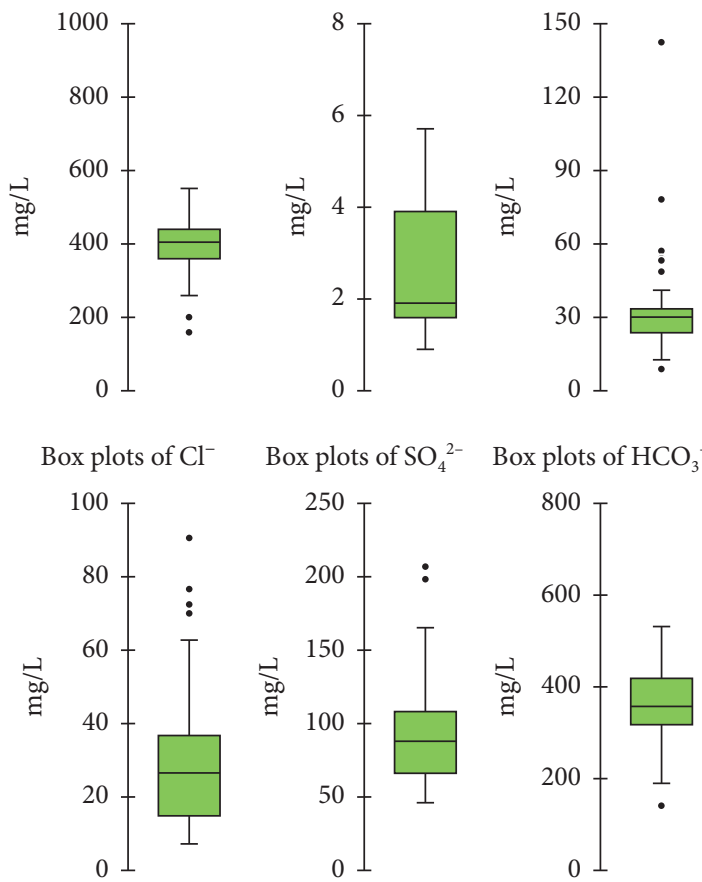

Box plots of $\mathrm{HCO}_{3}^{-}$

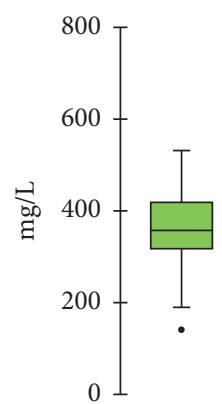

Box plots of $\mathrm{NH}_{4}^{+}$

Box plots of $\mathrm{F}^{-}$
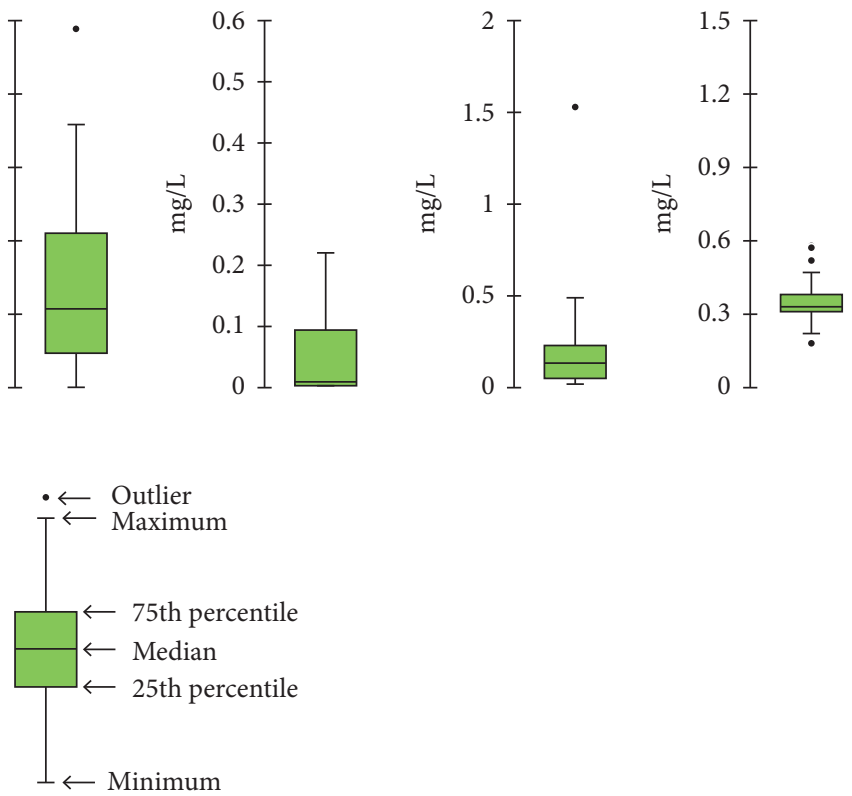

FIgURE 3: Box and Whisker plot of hydrochemical parameters of groundwater samples.

saturation indices of gypsum and halite were obviously lower than zero, implying the unsaturated state. Dolomite and calcite represented the oversaturated state by the saturation indices greater than zero. Hence, the hydrochemical compositions were mainly attributed to the dissolution of carbonate minerals.

3.3.3. Groundwater Quality Assessment Based on EWQI. The EWQI approach has been extensively used to evaluate the comprehensive effects of hydrochemical parameters on overall water quality $[25,26,39]$. The EWQI values lower than 100 imply that the water quality reaches the permissible limit for drinking purpose. In the present study, the concentrations of $\mathrm{Ca}^{2+}, \mathrm{Mg}^{2+}, \mathrm{Na}^{+}, \mathrm{K}^{+}, \mathrm{Cl}^{-}, \mathrm{SO}_{4}{ }^{2-}, \mathrm{HCO}_{3}{ }^{-}, \mathrm{F}^{-}$, $\mathrm{NO}_{3}{ }^{-}$, and TDS were involved in the computation of the EWQI. Herein, the EWQI values had a range of 95-235 (average value $=175$ ) and were evaluated from rank 2 to rank 5 (Figure 7(a)). The majority of groundwater samples displayed the levels of Rank: 4 poor, lower than permissible drinking standard of the WHO. 

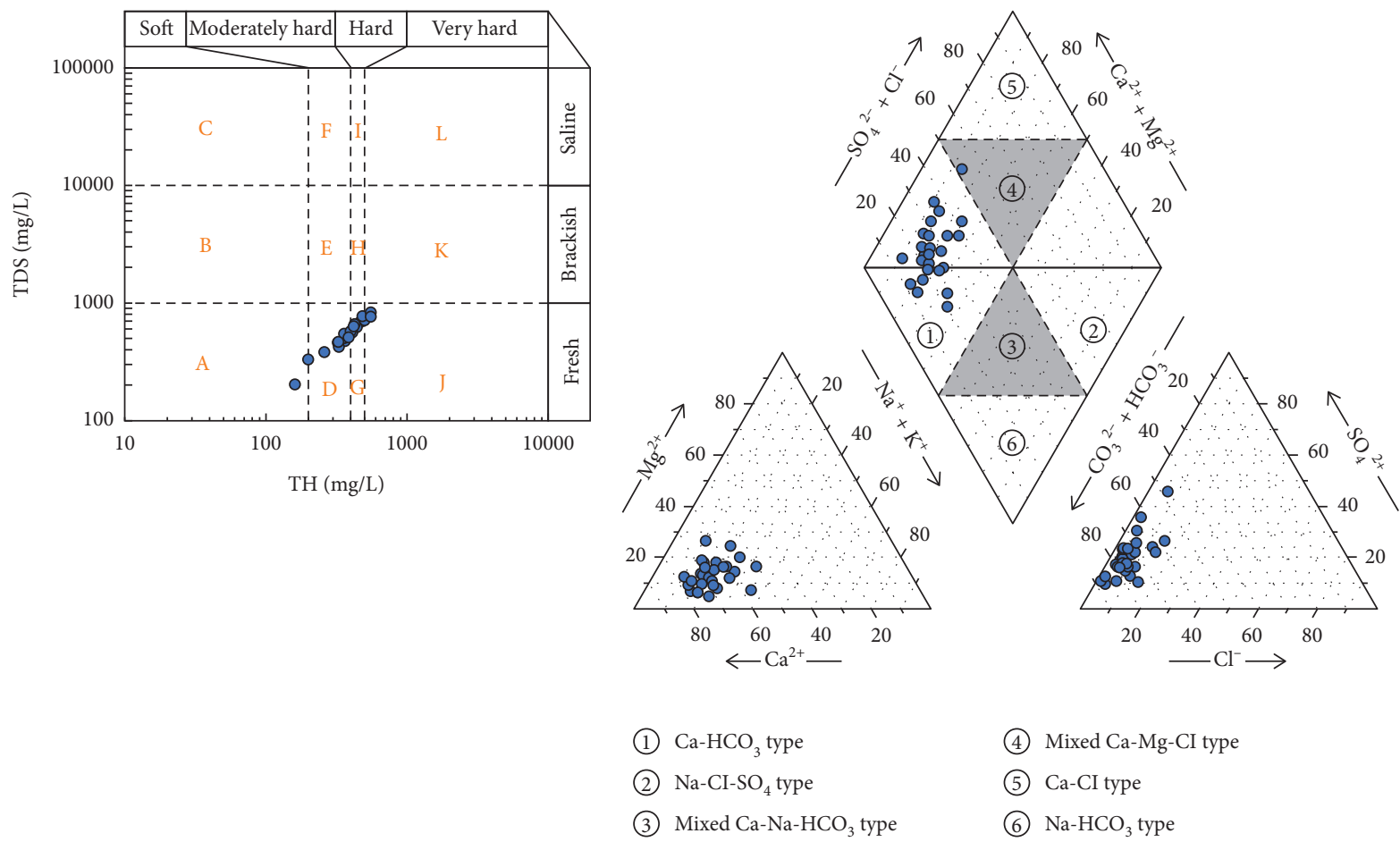

(a)

(b)

FIGURE 4: Scatter plots of (a) TH versus TDS demonstrating groundwater quality and (b) Piper trilinear diagram for groundwater samples.

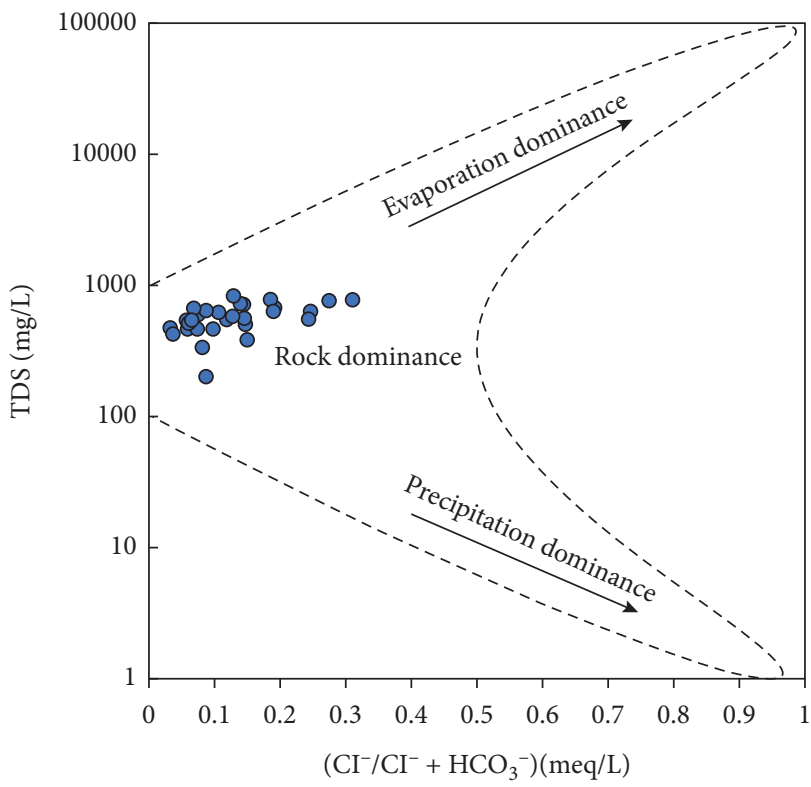

(a)

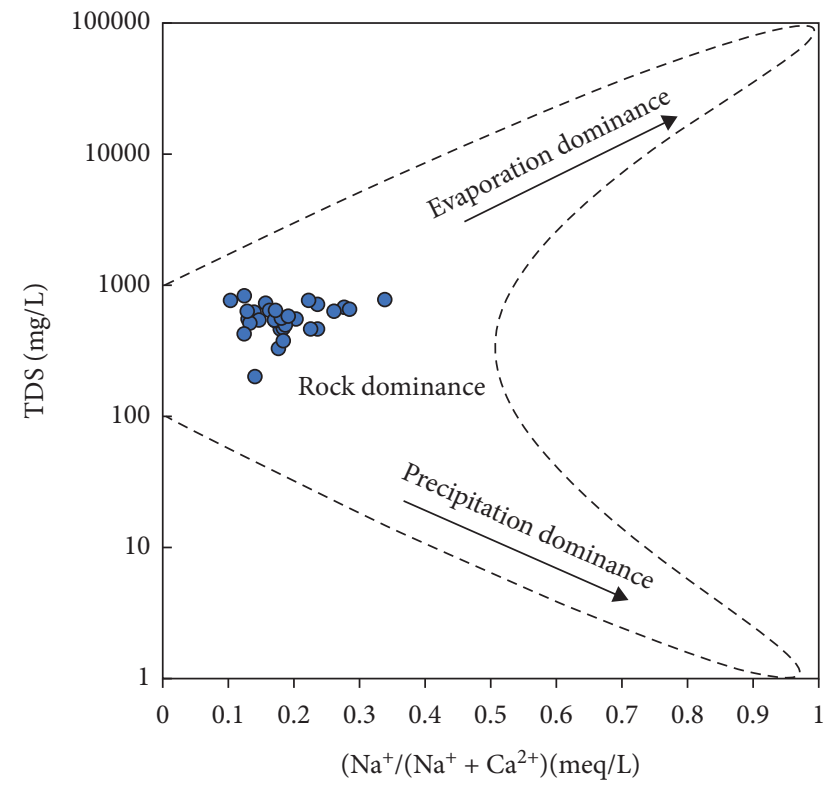

(b)

FIGURE 5: Gibbs diagrams demonstrating the mechanisms governing groundwater chemistry. (a) TDS $v s . \mathrm{Cl}^{-} /\left(\mathrm{Cl}^{-}+\mathrm{HCO}_{3}^{-}\right)$; (b) TDS $v$. $\mathrm{Na}^{+} /\left(\mathrm{Na}^{+}+\mathrm{Ca}^{2+}\right)$.

The spatial distribution of the EWQI rank was visualized by the normal Kriging interpolation approach in the Geography Information System software (GIS) (Figure 7(b)). In Figure 7(b), the groundwater samples in the vast majority of the study area were not allowable for drinking purpose.
Some local places in the western and middle parts of the study area had groundwater whose EWQI values largely exceeded the permissible limit for safe drinking. Therefore, the western and middle parts of the study area should be paid more attention for groundwater protection in future. 


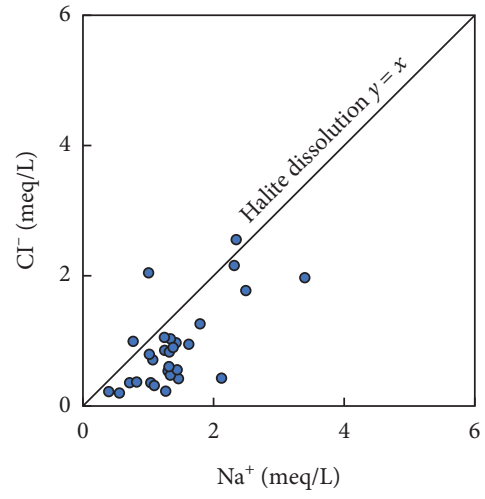

(a)

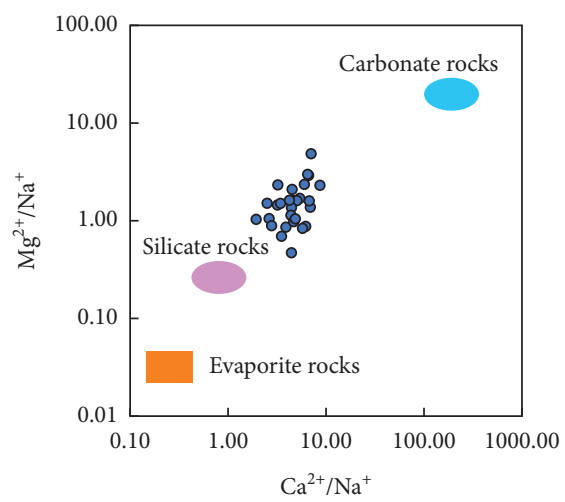

(d)

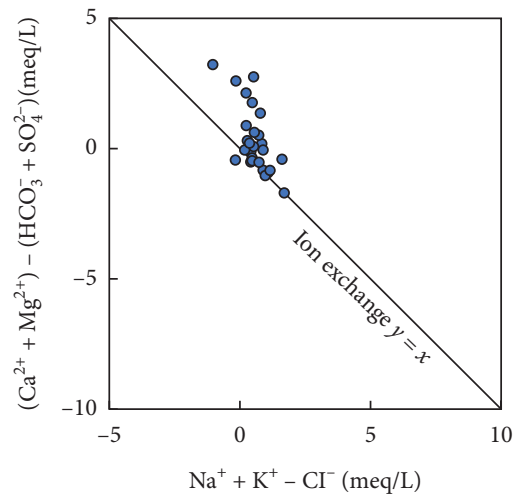

(g)

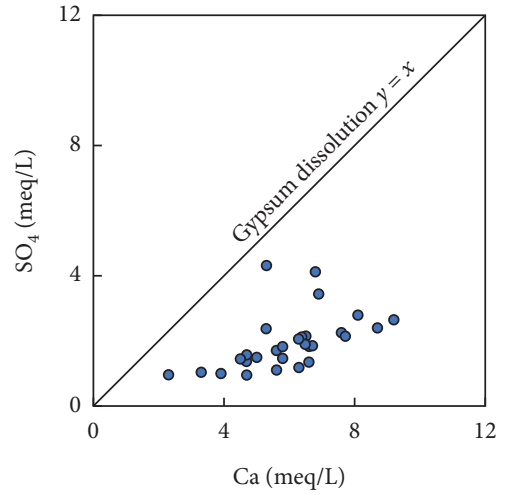

(b)

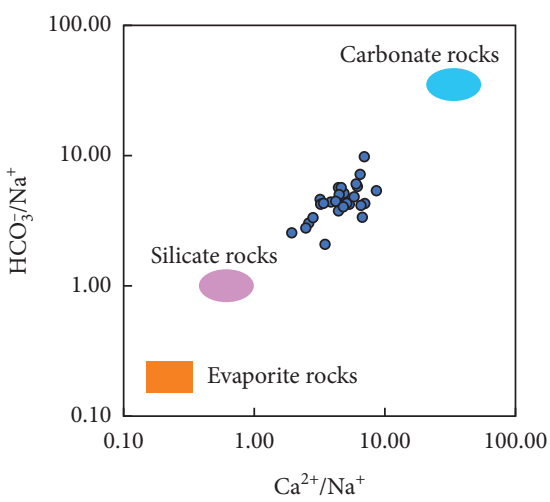

(e)

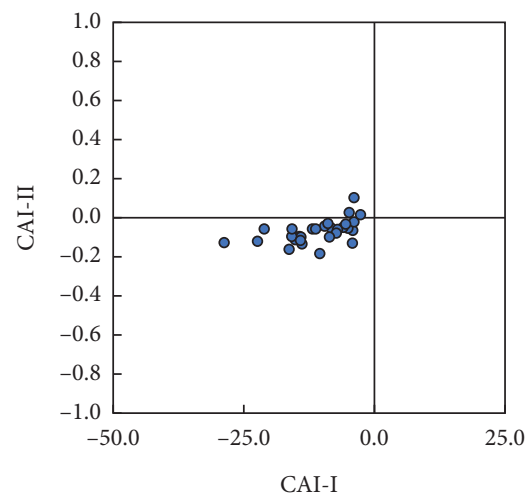

(h)

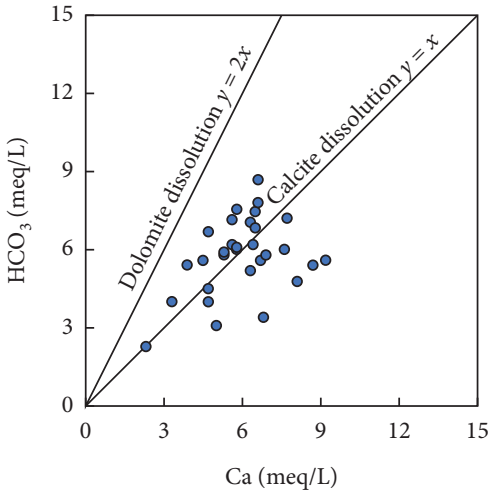

(c)

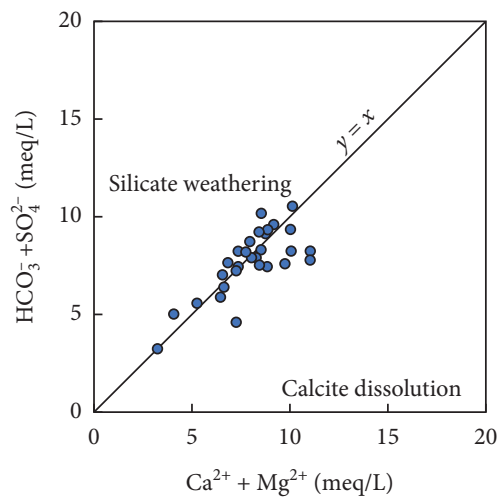

(f)

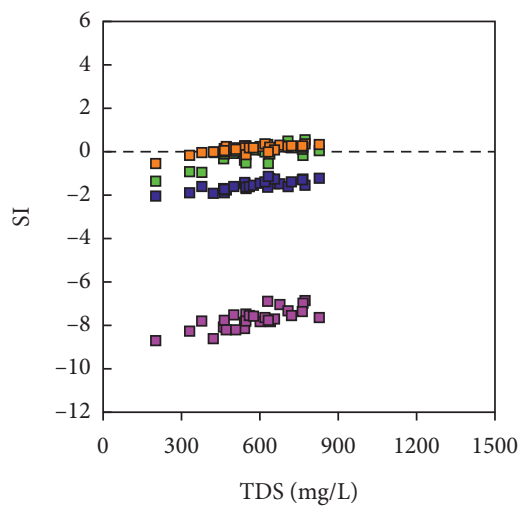

$\square$ Calcite

Gypsum

Dolomite

(i)

Figure 6: Correlation diagrams of (a) $\mathrm{Cl}^{-}$vs. $\mathrm{Na}^{+}$, (b) $\mathrm{SO}_{4}{ }^{2-}$ vs. $\mathrm{Ca}^{2+}$, (c) $\mathrm{HCO}_{3}{ }^{-}$vs. $\mathrm{Ca}^{2+}$, (d) $\left(\mathrm{Mg}^{2+} / \mathrm{Na}^{+}\right)$vs. $\left(\mathrm{Ca}^{2+} / \mathrm{Na}^{+}\right),(\mathrm{e})\left(\mathrm{HCO}_{3}{ }^{-} / \mathrm{Na}^{+}\right)$ vs. $\left(\mathrm{Ca}^{2+} / \mathrm{Na}^{+}\right)$, (f) $\mathrm{HCO}_{3}{ }^{-}+\mathrm{SO}_{4}{ }^{2-}$ vs. $\mathrm{Ca}^{2+}+\mathrm{Mg}^{2+}$, (g) $\left(\mathrm{Ca}^{2+}+\mathrm{Mg}^{2+}\right)-\left(\mathrm{HCO}_{3}{ }^{-}+\mathrm{SO}_{4}{ }^{2-}\right) v s . \mathrm{Na}^{+}+\mathrm{K}^{+}-\mathrm{Cl}^{-}$, (h) chloroalkaline indices CAII vs. CAI-II, and (i) SI vs. TDS. 


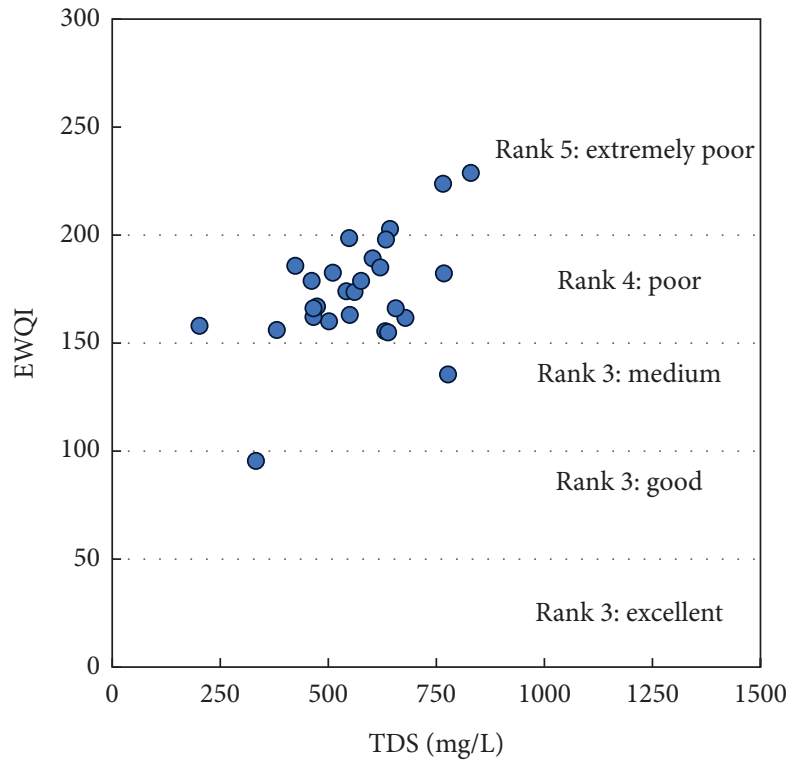

(a)

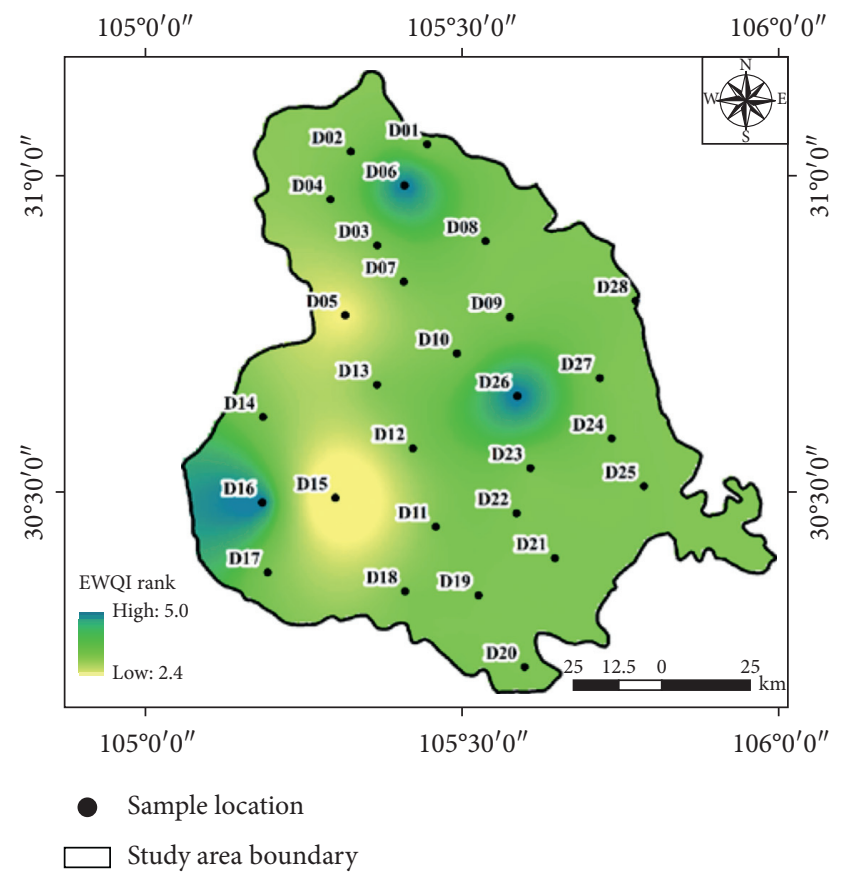

(b)

FIgURE 7: (a) The relationship between the entropy-weighted water quality index (EWQI) and TDS and (b) spatial distribution of groundwater quality based on the EWQI rank.

\section{Conclusions}

In this study, twenty-eight groundwater samples were collected from the Suining area for hydrogeochemical analysis and quality assessment in order to better exploit and utilize groundwater resources. The main conclusions were drawn as follows:

(1) Groundwater samples represented alkaline affinity and high TDS values with $\mathrm{Ca}-\mathrm{HCO}_{3}$ type. The average cation and anion concentrations followed the order of $\mathrm{Ca}^{2+}>\mathrm{Na}^{+}>\mathrm{Mg}^{2+}>\mathrm{K}^{+}$and $\mathrm{HCO}_{3}{ }^{-}>$ $\mathrm{SO}_{4}{ }^{2-}>\mathrm{Cl}^{-}>\mathrm{NO}_{3}{ }^{-}>\mathrm{F}^{-}$. Nitrate contamination was identified by the $\mathrm{NO}_{3}{ }^{-}$concentrations of $0.20-244.00 \mathrm{mg} / \mathrm{L}$.

(2) Ratios of major ions and geochemical modelling collectively revealed that hydrogeochemical compositions were dominated by carbonate dissolution and ion exchange.

(3) Entropy-weighted water quality index (EWQI) indicated that most of the total samples were unsuitable for drinking. The western and middle parts of the study area with higher EWQI values should be paid more attention for groundwater protection in future.

\section{Data Availability}

The data used to support the findings of the present study are available from the corresponding author upon request.

\section{Conflicts of Interest}

The authors declare that they have no conflicts of interest.

\section{Acknowledgments}

This research was funded by the Natural Science Foundation of China (42072313), the Fundamental Research Funds for the Central Universities (2682020CX10), and the Student Research Training Program of Southwest Jiaotong University (202010613072 and 201019).

\section{References}

[1] J. Wu, J. Bian, H. Wan, Y. Ma, and X. Sun, "Health risk assessment of groundwater nitrogen pollution in Songnen Plain," Ecotoxicology and Environmental Safety, vol. 207, Article ID 111245, 2021.

[2] S. Chen, Z. Tang, J. Wang et al., "Multivariate analysis and geochemical signatures of shallow groundwater in the main urban area of chongqing, southwestern China," Water, vol. 12, no. 10 , p. $2833,2020$.

[3] N. Adimalla, H. Qian, and M. J. Nandan, "Groundwater chemistry integrating the pollution index of groundwater and evaluation of potential human health risk: a case study from hard rock terrain of south India," Ecotoxicology and Environmental Safety, vol. 206, Article ID 111217, 2020.

[4] G. Zhu, X. Wu, J. Ge, F. Liu, W. Zhao, and C. Wu, "Influence of mining activities on groundwater hydrochemistry and heavy metal migration using a self-organizing map (SOM)," Journal of Cleaner Production, vol. 257, Article ID 120664, 2020.

[5] M. Hossain and P. K. Patra, "Hydrogeochemical characterisation and health hazards of fluoride enriched groundwater in diverse aquifer types," Environmental Pollution, vol. 258, Article ID 113646, 2020.

[6] A. Banning, "Geogenic arsenic and uranium in Germany: large-scale distribution control in sediments and 
groundwater," Journal of Hazardous Materials, vol. 405, Article ID 124186, 2020.

[7] Y. Teng, R. Zuo, Y. Xiong, J. Wu, Y. Zhai, and J. Su, "Risk assessment framework for nitrate contamination in groundwater for regional management," Science of The Total Environment, vol. 697, Article ID 134102, 2019.

[8] J. Qiao, Y. Zhu, X. Jia, M. a. Shao, X. Niu, and J. Liu, "Distributions of arsenic and other heavy metals, and health risk assessments for groundwater in the Guanzhong Plain region of China," Environmental Research, vol. 181, Article ID 108957, 2020.

[9] P. Li and H. Qian, "Water resources research to support a sustainable China," International Journal of Water Resources Development, vol. 34, no. 3, pp. 327-336, 2018.

[10] X. Gao, X. Li, W. Wang, and C. Li, "Human activity and hydrogeochemical processes relating to groundwater quality degradation in the yuncheng basin, northern China," International Journal of Environmental Research and Public Health, vol. 17, no. 3, p. 867, 2020.

[11] J. Li, "Evaluating spatiotemporal variations of groundwater quality in northeast beijing by self-organizing map," Water, vol. 12, no. 5, 2020.

[12] Y. Zhang, Y. Dai, Y. Wang, X. Huang, Y. Xiao, and Q. Pei, "Hydrochemistry, quality and potential health risk appraisal of nitrate enriched groundwater in the Nanchong area, southwestern China," Science of The Total Environment, vol. 784, Article ID 147186, 2021.

[13] C. Li, X. Gao, S. Li, and J. Bundschuh, "A review of the distribution, sources, genesis, and environmental concerns of salinity in groundwater," Environmental Science and Pollution Research, vol. 27, no. 33, pp. 41157-41174, 2020.

[14] C. Li, X. Gao, Y. Liu, and Y. Wang, "Impact of anthropogenic activities on the enrichment of fluoride and salinity in groundwater in the Yuncheng Basin constrained by $\mathrm{Cl} / \mathrm{Br}$ ratio, $\delta 18 \mathrm{O}, \delta 2 \mathrm{H}, \delta 13 \mathrm{C}$ and $\delta 7 \mathrm{Li}$ isotopes," Journal of $\mathrm{Hy}$ drology, vol. 579, Article ID 124211, 2019.

[15] Y. Xiao, "Hydrogeochemical features and genesis of confined groundwater and health perspectives for sustainable development in urban hengshui, north China plain," Journal of Chemistry, vol. 2021, Article ID 5578192, 15 pages, 2021.

[16] Y. Luo, "Groundwater geochemical signatures and implication for sustainable development in a typical endorheic watershed on Tibetan plateau," Environmental Science and Pollution Research, 2021.

[17] Y. Zhou, P. Li, L. Xue, Z. Dong, and D. Li, "Solute geochemistry and groundwater quality for drinking and irrigation purposes: a case study in Xinle City, North China," Geochemistry, vol. 80, no. 4, Article ID 125609, 2020.

[18] S. He, P. Li, J. Wu, V. Elumalai, and N. Adimalla, "Groundwater quality under land use/land cover changes: a temporal study from 2005 to 2015 in Xi'an, Northwest China," Human and Ecological Risk Assessment: An International Journal, vol. 26, no. 10, pp. 2771-2797, 2020.

[19] P. Li, X. He, and W. Guo, "Spatial groundwater quality and potential health risks due to nitrate ingestion through drinking water: a case study in Yan'an City on the Loess Plateau of northwest China," Human and Ecological Risk Assessment: An International Journal, vol. 25, no. 2, pp. 11-31, 2019.

[20] J. Li, Z. Shi, M. Liu, G. Wang, F. Liu, and Y. Wang, "Identifying anthropogenic sources of groundwater contamination by natural background levels and stable isotope application in Pinggu basin, China," Journal of Hydrology, vol. 596, Article ID 126092, 2021.
[21] S. Qu, Z. Shi, X. Liang, G. Wang, and J. Han, "Multiple factors control groundwater chemistry and quality of multi-layer groundwater system in Northwest China coalfield - using selforganizing maps (SOM)," Journal of Geochemical Exploration, vol. 227, Article ID 106795, 2021.

[22] N. Adimalla and H. Qian, "Groundwater quality evaluation using water quality index (WQI) for drinking purposes and human health risk (HHR) assessment in an agricultural region of Nanganur, south India," Ecotoxicology and Environmental Safety, vol. 176, pp. 153-161, 2019.

[23] M. Dhanasekarapandian, S. Chandran, D. S. Devi, and V. Kumar, "Spatial and temporal variation of groundwater quality and its suitability for irrigation and drinking purpose using GIS and WQI in an urban fringe," Journal of African Earth Sciences, vol. 124, pp. 270-288, 2016.

[24] S. Krishna Kumar, R. Bharani, N. S. Magesh, P. S. Godson, and N. Chandrasekar, "Hydrogeochemistry and groundwater quality appraisal of part of south Chennai coastal aquifers, Tamil Nadu, India using WQI and fuzzy logic method," Applied Water Science, vol. 4, no. 4, pp. 341-350, 2014.

[25] N. Adimalla, Application of the Entropy Weighted Water Quality Index (EWQI) and the Pollution Index of Groundwater (PIG) to Assess Groundwater Quality for Drinking Purposes: A Case Study in a Rural Area of Telangana State, Archives of Environmental Contamination and Toxicology, India, 2021.

[26] M. S. U. Hasan and A. K. Rai, "Groundwater quality assessment in the Lower Ganga Basin using entropy information theory and GIS," Journal of Cleaner Production, vol. 274, Article ID 123077, 2020.

[27] N. Adimalla, H. Qian, and P. Li, "Entropy water quality index and probabilistic health risk assessment from geochemistry of groundwaters in hard rock terrain of Nanganur County, South India," Geochemistry, vol. 80, no. 4, Article ID 125544, 2020.

[28] J. Liu, Y. Peng, C. Li, Z. Gao, and S. Chen, "Characterization of the hydrochemistry of water resources of the Weibei Plain, Northern China, as well as an assessment of the risk of high groundwater nitrate levels to human health," Environmental Pollution, vol. 268, Article ID 115947, 2021.

[29] C. Wu, X. Wu, C. Qian, and G. Zhu, "Hydrogeochemistry and groundwater quality assessment of high fluoride levels in the Yanchi endorheic region, northwest China," Applied Geochemistry, vol. 98, pp. 404-417, 2018.

[30] H.-W. Cao, G.-M. Li, R.-Q. Zhang et al., "Genesis of the Cuonadong tin polymetallic deposit in the Tethyan Himalaya: evidence from geology, geochronology, fluid inclusions and multiple isotopes," Gondwana Research, vol. 92, pp. 72-101, 2021.

[31] S. Liu, Y. Yang, B. Deng et al., "Tectonic evolution of the sichuan basin, southwest China," Earth-Science Reviews, vol. 213, Article ID 103470, 2021.

[32] M. Dietmar, Standards for Groundwater Quality, Standards Press of China, Beijing, China, 2017.

[33] World Health Organization, Guidelines for Drinking-Water Quality, World Health Organization, Geneva, Switzerland, 4th edition, 2011.

[34] R. J. Gibbs, "Mechanisms controlling world water chemistry," Science, vol. 170, no. 3962, pp. 1088-1090, 1970.

[35] J. Gaillardet, "Global silicate weathering and CO2 consumption rates deduced from the chemistry of large rivers," Chemical Geology, vol. 159, no. 1, pp. 3-30, 1999.

[36] Y. Xiao, X. Gu, S. Yin, X. Pan, J. Shao, and Y. Cui, "Investigation of geochemical characteristics and controlling 
processes of groundwater in a typical long-term reclaimed water use area," Water, vol. 9, no. 10, 800 pages, 2017.

[37] E. P. Tziritis, P. S. Datta, and R. Barzegar, "Characterization and assessment of groundwater resources in a complex hydrological basin of Central Greece (kopaida basin) with the joint use of hydrogeochemical analysis, multivariate statistics and stable isotopes," Aquatic Geochemistry, vol. 23, 2017.

[38] M. Sudheer Kumar, "Principal component and multivariate statistical approach for evaluation of hydrochemical characterization of fluoride-rich groundwater of Shaslar Vagu watershed, Nalgonda District, India," Arabian Journal of Geosciences, vol. 10, no. 4, 2017.

[39] N. Adimalla, H. Qian, and P. Li, "Entropy Water Quality Index and Probabilistic Health Risk Assessment from Geochemistry of Groundwaters in Hard Rock Terrain of Nanganur County, South India," Geochemistry, vol. 80, Article ID 125544, 2019. 